\title{
Raman spectroscopy as a tool for monitoring mesoscale continuous-flow organic synthesis: Equipment interface and assessment in four medicinally-relevant reactions
}

\author{
Trevor A. Hamlin and Nicholas E. Leadbeater*
}

\section{Full Research Paper}

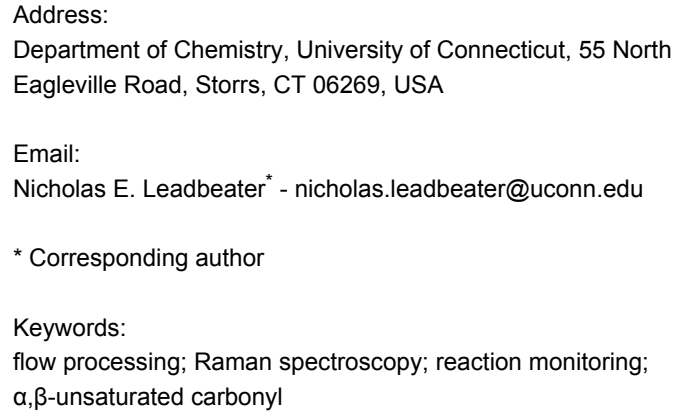

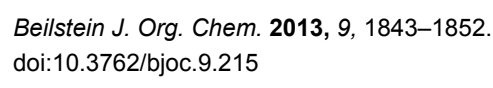

(C) 2013 Hamlin and Leadbeater; licensee Beilstein-Institut. License and terms: see end of document.

\begin{abstract}
An apparatus is reported for real-time Raman monitoring of reactions performed using continuous-flow processing. Its capability is assessed by studying four reactions, all involving formation of products bearing $\alpha, \beta$-unsaturated carbonyl moieties; synthesis of 3-acetylcoumarin, Knoevenagel and Claisen-Schmidt condensations, and a Biginelli reaction. In each case it is possible to monitor the reactions and also in one case, by means of a calibration curve, determine product conversion from Raman spectral data as corroborated by data obtained using NMR spectroscopy.
\end{abstract}

\section{Introduction}

Continuous-flow processing is used in the chemical industry on production scales. In a research and development setting, there has been increasing interest in using flow chemistry on smaller scales. To this end, a wide range of companies now produce equipment for both micro- and mesofluidic flow chemistry $[1,2]$. Some of the advantages of these devices are increased experimental safety, easy scale-up and thorough mixing of reagents [3-7]. It is not surprising, therefore, that a wide range of synthetic chemistry transformations have been reported using this equipment $[8,9]$. When it comes to evaluating the outcome of reactions performed using flow chemistry and optimizing reaction conditions, one option is to use inline product analysis. This opens the avenue for fast, reliable assay in comparison with the traditional approach in which performance is evaluated based on offline product analysis. When interfaced with microreactors, inline analysis has taken significant strides in recent years $[7,10]$. Spectroscopic tools such as infrared [1115], UV-visible [16-18], NMR [19,20], Raman [21-25], and mass spectrometry [26,27] have all been interfaced with success. There have been less reports when it comes to 
mesoflow systems. Perhaps most developed is the area of infrared monitoring. The now ubiquitous ReactIR equipment has been interfaced with commercially available flow equipment to allow for real-time analysis of reactions and on-the-fly optimization of conditions [28-30].

In our laboratory we have had success interfacing a Raman spectrometer with a scientific microwave unit [31]. This has allowed us to monitor reactions from both a qualitative [32-35] and quantitative [36,37] perspective. A recent report of the use of Raman spectroscopy for monitoring a continuous-flow palladium-catalyzed cross-coupling reaction [38] sparked our interest in interfacing our Raman spectrometer with one of our continuous-flow units and employing it for inline reaction monitoring of a number of key medicinally-relevant organic transformations. Our results are presented here.

\section{Results and Discussion Interfacing the spectrometer to the flow unit}

In interfacing our Raman spectrometer with a continuous-flow reactor, our objective was to use a similar approach to that which proved successful when using microwave heating. Borosilicate glass is essentially "Raman transparent". Therefore reactions could be monitored by placing a Raman probe near the reaction vessel, without requirement to place any parts of the spectrometer inside the reaction vessel. The exposure of metallic components to the microwave field was avoided using a quartz light-pipe extending both the excitation laser and the acquisition fiber optic components of the spectrometer almost without any loss of light. The optimum distance of the lightpipe to the outside wall of the reaction vessel was found to be approximately $0.5 \mathrm{~mm}$. Moving to our continuous-flow reactor, we decided to place the spectroscopic interface just after the back-pressure regulator assembly. This meant that we did not need to engineer a flow cell capable of holding significant pressure. Instead we used an off-the-shelf flow cell traditionally used in conjunction with other spectroscopic monitoring tools. The cell had screw-threaded inlet and outlet tubes of the same diameter as the tubing of the flow unit (i.d. $1 \mathrm{~mm}$ ). The sample chamber had a width of $6.5 \mathrm{~mm}$, height of $20 \mathrm{~mm}$ and a path length of $5 \mathrm{~mm}$ giving the cell a nominal internal volume of $0.210 \mathrm{~mL}$ (Figure 1a). We built an assembly to allow us to hold the cell in a fixed location and vary the distance of the quartz light-pipe so as to optimize the Raman signal intensity. The apparatus is shown in Figure $1 \mathrm{~b}$.

\section{Testing the interface: The synthesis of 3-acetylcoumarin}

As our first reaction for study, we selected the piperidinecatalyzed synthesis of 3-acetylcoumarin (1) from salicylaldehyde with ethyl acetoacetate (Scheme 1). We had extensive

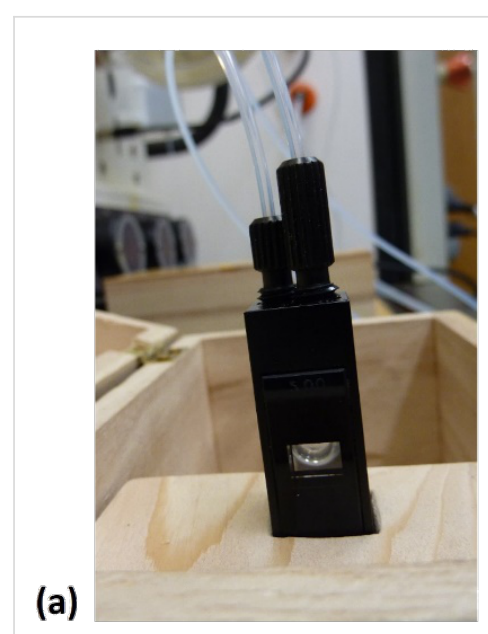

(b)

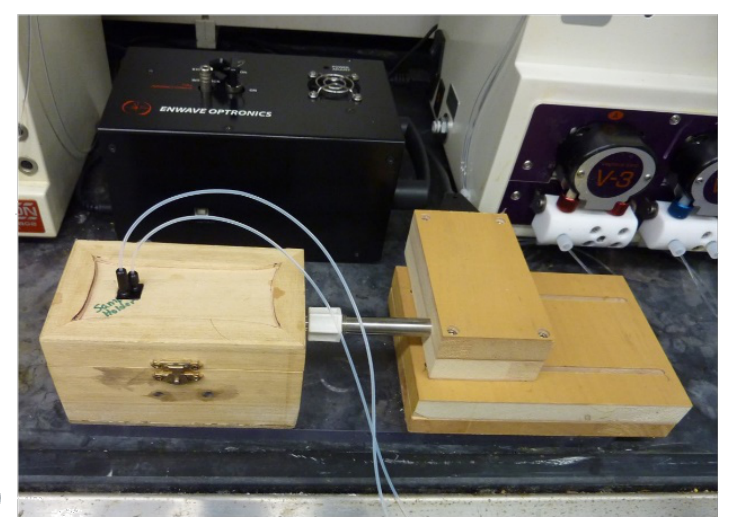

Figure 1: (a) Flow cell and (b) Raman interface used in the present study.

experience of monitoring this reaction both qualitatively [32] and quantitatively [36] when using microwave heating so believed it would be a good starting point for our present study. The reaction works well when using ethyl acetate as the solvent. However, $\mathbf{1}$ is not completely soluble at room temperature. To overcome potential clogging of the back-pressure regulator as well as mitigating the risk of having solid particles in the flow cell (which would perturb signal acquisition), we leveraged a technique we developed for this and other reactions previously [39]. Once the reaction stream has exited the heated zone, it is intercepted with a flow of a suitable organic solvent. This solubilizes the product and allows it to pass through the back-pres-

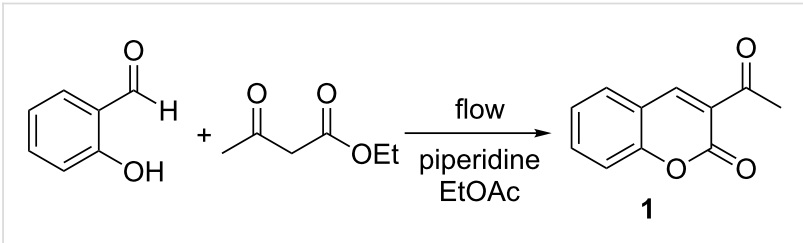

Scheme 1: The reaction between salicylaldehyde and ethyl acetoacetate to form 3-acetyl coumarin (1). 
sure regulator unimpeded. In the case of $\mathbf{1}$, we intercept the product stream with a flow of acetone.

Our first objective was to determine whether we could observe spectroscopically a slug of the coumarin passing through the flow cell. The Raman spectrum of 1 (Figure 2) exhibits strong Raman-active stretching modes at $1608 \mathrm{~cm}^{-1}$ and $1563 \mathrm{~cm}^{-1}$ while the salicylaldehyde and ethyl acetoacetate starting materials exhibit minimal Raman activity in this area. As a result, we chose to monitor the $1608 \mathrm{~cm}^{-1}$ signal. To mimic a product mixture, we pumped a solution of $\mathbf{1}$ in acetone through our flow reactor, intercepted it with an equal volume of ethyl acetate and passed this mixture through the flow cell. We recorded a Raman spectrum every $15 \mathrm{~s}$ in an automated fashion as the coumarin passed through the cell by using the "continuous-scan" function on our spectrometer. By subtracting the spectrum of the solvent mixture (1:1 ethyl acetate:acetone) from the spectra recorded, we were able to clearly see the growth of the signal due to $\mathbf{1}$ followed by a plateau as it passed through the cell and then a drop back to the baseline as the final aliquot exited (Figure 3).

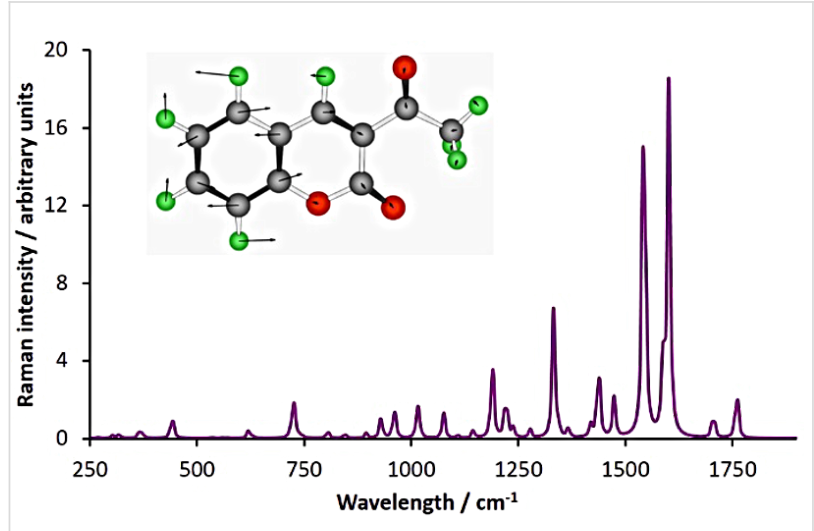

Figure 2: The Raman spectrum of 3-acetylcoumarin (1) generated using Gaussian 09 [40] at the B3LYP/6-31g(d) level of theory. The inset molecule illustrates the stretching mode responsible for the signal calculated at $1602 \mathrm{~cm}^{-1}$ (actual: $1608 \mathrm{~cm}^{-1}$ ).

Knowing we could observe the product as it passed through the flow cell, we next performed the complete reaction. As a starting point, we chose as conditions a flow rate of $1 \mathrm{~mL} / \mathrm{min}$ through a $10 \mathrm{~mL}$ PFA coil at room temperature. We were indeed able to monitor the reaction as shown in Figure 4. In an effort to optimize the reaction conditions, we varied both the temperature of the reactor coil and also the flow rate, monitoring each run and then compiling the data (Figure 4). While increasing the reaction temperature to $130{ }^{\circ} \mathrm{C}$ led to a marked increase in product conversion, reducing the flow rate from $1 \mathrm{~mL} / \mathrm{min}$ to $0.5 \mathrm{~mL} / \mathrm{min}$ at this temperature did not have a significant impact on the outcome of the reaction.

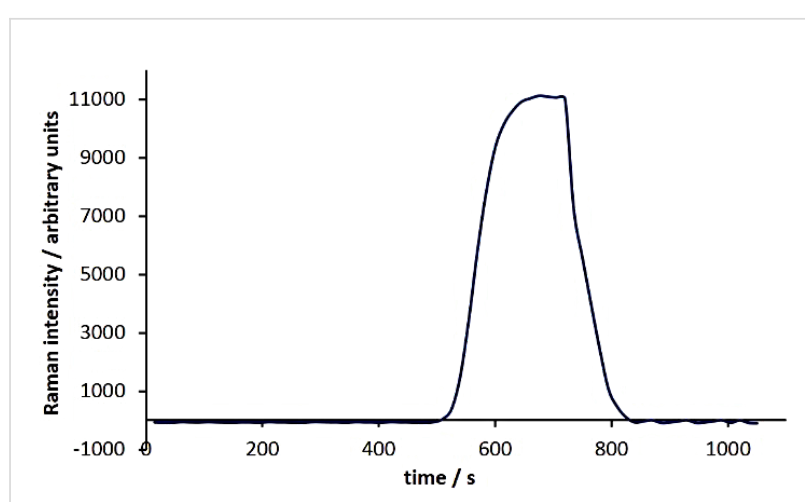

Figure 3: Monitoring an aliquot of 3-acetyl coumarin (1) as it passes through the flow cell (scan time $=15 \mathrm{~s}$, integration $=10 \mathrm{~s}$ ).

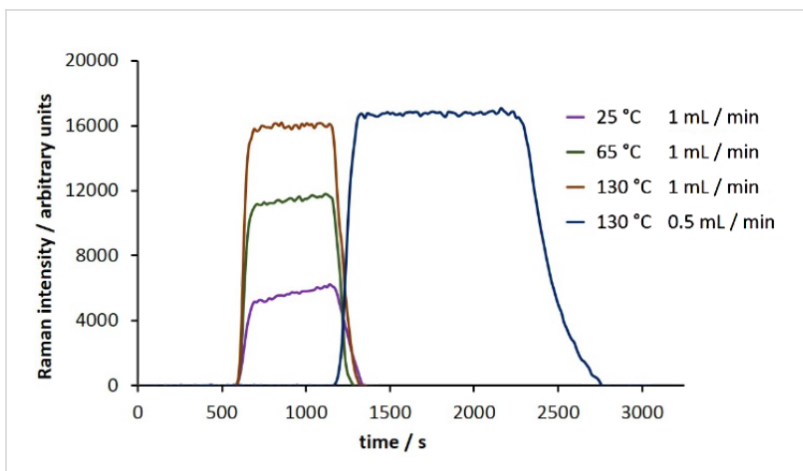

Figure 4: Monitoring the conversion of salicylaldehyde and ethyl acetoacetate to 3 -acetylcoumarin (1) across a range of reaction conditions $($ scan time $=15 \mathrm{~s}$, integration $=10 \mathrm{~s})$.

In an attempt to quantify product conversion, we needed next to obtain a calibration curve to allow us to convert units of Raman intensity to units of concentration in standard terms. To achieve this, we passed solutions of various concentrations of 3-acetylcoumarin (3) in ethyl acetate/acetone through the flow cell and collected the Raman spectrum. When the signal intensity at $1608 \mathrm{~cm}^{-1}$ is plotted against concentration, after subtraction of signals due to the solvent, the result is a straight line (Figure 5).

The Stokes shift (which is being monitored) is inversely proportional to the temperature. Since the flow cell is situated after the product mixture exits the heated zone and because of the very efficient heat transfer observed using narrow-gauge tubing, the product mixture was essentially at room temperature by the time it passed through the flow cell. As a result, it was not deemed necessary to involve a scaling factor to account for temperature effects.

With the appropriate calibration curve in hand, we were able to obtain product conversion values for each set of reaction conditions screened, taking into account the fact that the product 


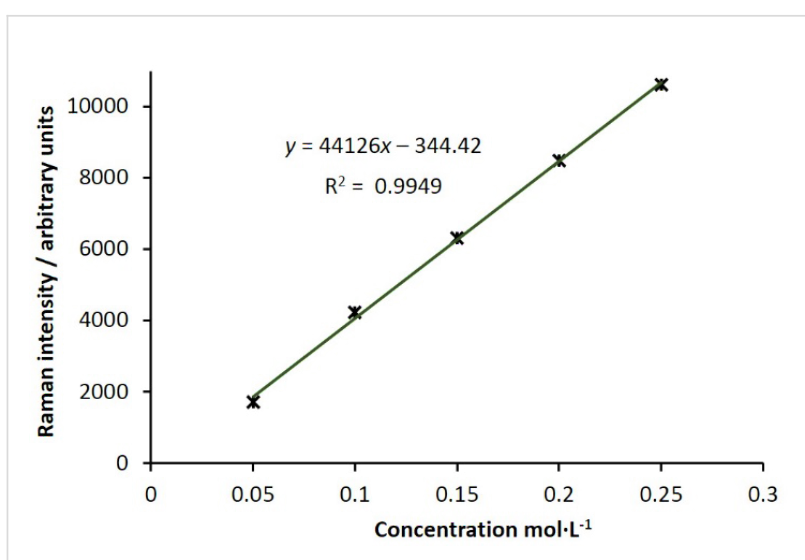

Figure 5: Plot of Raman intensity of the peak arising at $1608 \mathrm{~cm}^{-1} \mathrm{vs}$ concentration of 3-acetyl coumarin (1), yielding a straight line, $y=m x+$ $\mathrm{b} ; \mathrm{m}=$ Raman intensity $\cdot \mathrm{M}^{-1}$ of $\mathbf{1}$.

concentration is halved by the interception with acetone. To determine their accuracy, we also determined product conversion using NMR spectroscopy. Comparison of the values shows a good correlation (Table 1).

\section{Expanding the technique to other reactions The Knovenagel condensation}

We turned our attention next to the Knoevenagel condensation of ethyl acetoacetate with a range of aromatic aldehydes (Scheme 2). Our objective was to optimize conditions using one aldehyde substrate spectroscopically from a qualitative standpoint and then screen other examples. We chose benzaldehyde as our initial substrate, ethyl acetate as the solvent and piperidine as a base catalyst. In order to determine the optimal spectral frequency at which to monitor we wanted to find a quick way to derive the Raman spectrum of the product 2a. As was the case with $\mathbf{1}$, this could be achieved computationally using Gaussian 09 at the B3LYP/6-31g(d) level of theory [40], and a signal at $1598 \mathrm{~cm}^{-1}$ selected for monitoring.

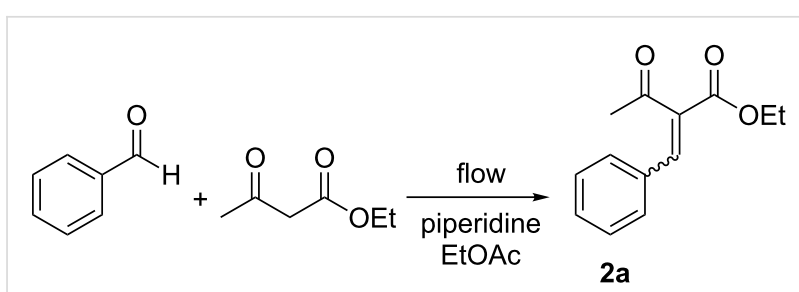

Scheme 2: The Knoevenagel condensation of benzaldehyde and ethyl acetoacetate to yield (Z)-ethyl 2-benzylidene-3-oxobutanoate (2a).

Performing the reaction across a range of conditions, flowing the reaction mixture at $1 \mathrm{~mL} / \mathrm{min}$ through the $10 \mathrm{~mL}$ coil heated to $130{ }^{\circ} \mathrm{C}$ proved to be optimal (Figure 6). A $67 \%$ conversion to 2a was obtained, as determined by GC analysis. Purification of the product mixture gave a $60 \%$ isolated yield of the $Z$-isomer of $2 \mathbf{a}$. Using these optimized reaction conditions, we screened

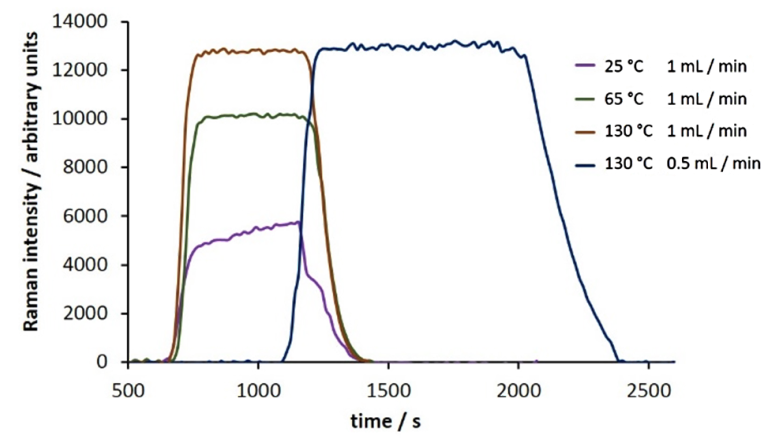

Conditions Conversion to 2a (\%)

$\begin{array}{cc}25^{\circ} \mathrm{C}, 1 \mathrm{~mL} / \mathrm{min} & 40 \\ 65^{\circ} \mathrm{C}, 1 \mathrm{~mL} / \mathrm{min} & 63 \\ 130^{\circ} \mathrm{C}, 1 \mathrm{~mL} / \mathrm{min} & 67 \\ 130^{\circ} \mathrm{C}, 0.5 \mathrm{~mL} / \mathrm{min} & 68\end{array}$

Figure 6: Monitoring the conversion of benzaldehyde and ethyl acetoacetate to (Z)-ethyl 2-benzylidene-3-oxobutanoate (2a) across a range of reaction conditions (scan time $=15 \mathrm{~s}$, integration $=10 \mathrm{~s}$ ).

Table 1: Comparison of product conversion values obtained from Raman spectra with those obtained using NMR spectroscopy for the conversion of salicylaldehyde and ethyl acetoacetate to 3 -acetylcoumarin (1).

Conditions

Concentration of 1 when
diluted with acetone
$\quad\left(\mathrm{mol} \mathrm{L}^{-1}\right)$

Raman monitoring

Concentration of 1 after normalizing for dilution by acetone $\left(\mathrm{mol} \mathrm{L}^{-1}\right)$
Conv. (\%)

NMR

$\begin{array}{ccccc}25^{\circ} \mathrm{C}, 1 \mathrm{~mL} / \mathrm{min} & 0.125 & 0.25 & 25 & 22 \\ 65^{\circ} \mathrm{C}, 1 \mathrm{~mL} / \mathrm{min} & 0.27 & 0.55 & 55 & 58 \\ 130^{\circ} \mathrm{C}, 1 \mathrm{~mL} / \mathrm{min} & 0.37 & 0.74 & 74 & 79 \\ 130^{\circ} \mathrm{C}, 0.5 \mathrm{~mL} / \mathrm{min} & 0.39 & 0.78 & 78 & 80\end{array}$


Table 2: Product conversion obtained for four aldehyde substrates in the Knoevenagel reaction with ethyl acetoacetate.

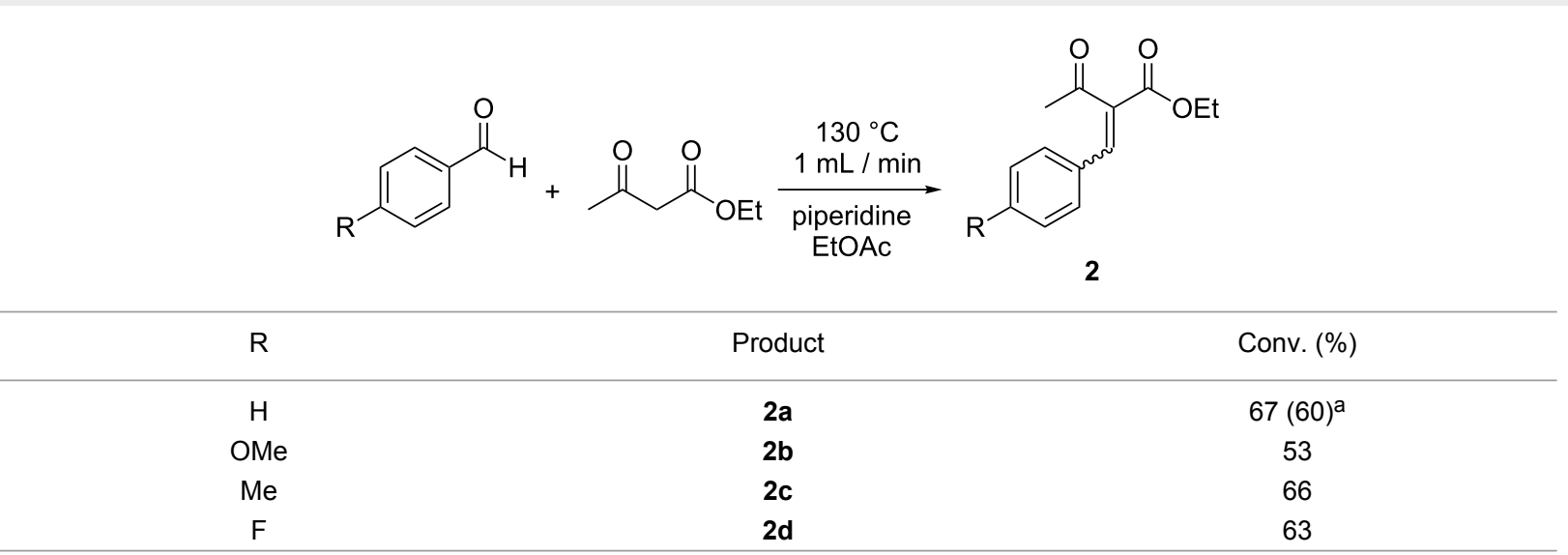

asolated yield.

three para-substituted aldehyde substrates (Table 2). As expected, placing an electron-donating methoxy group on the aromatic ring led to lower product conversion as compared to benzaldehyde (Table 2, entry 2). A methyl- or fluoro-substituent has little effect on the outcome of the reaction (Table 2, entries 3 and 4$)$.

\section{The Claisen-Schmidt condensation}

We moved next to study the Claisen-Schmidt condensation of benzaldehyde with acetophenone to yield chalcone (Scheme 3). Chalcones display interesting biological properties such as antioxidant, cytotoxic, anticancer, antimicrobial, antiprotozoal, antiulcer, antihistaminic, and anti-inflammatory activity [41]. They are also intermediates on the way to highly fluorescent cyanopyridine and deazalumazine dyes [42]. The calculated Raman spectrum of the product 3a shows a very strong signal at $1604 \mathrm{~cm}^{-1}$ which was selected for monitoring. Using sodium hydroxide as the catalyst, the reaction was monitored under a range of reaction conditions (Figure 7). We fast discovered that at temperatures in excess of $65{ }^{\circ} \mathrm{C}$ we observed decomposition or else formation of a highly fluorescent byproduct, as evidenced by collapse of the Raman spectrum. We also observed a significant "tail" on the plot of signal intensity at $1604 \mathrm{~cm}^{-1} \mathrm{vs}$ time. We attribute this to the fact that the chalcone product is very highly Raman active and even a trace in the flow cell can

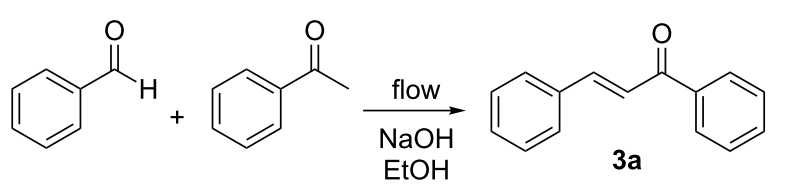

Scheme 3: Claisen-Schmidt condensation of benzaldehyde with acetophenone to yield chalcone, $3 \mathbf{a}$. be readily detected. It does however highlight the fact that there may be both significant dispersion along the length of the reactor and the product is slow in clearing the flow cell. Dispersion is the consequence of laminar flow and some of the material takes longer to travel through the reactor than the rest. Thus, when a flow reactor is used to process a finite volume of reagents, the leading and trailing ends of the product emerging from the end of the reactor will have mixed to some extent with the solvent that preceded or followed it. This means that there are zones at the leading and trailing ends of the product stream in which the concentration of product is variable. Our optimal conditions for the reaction were heating at $65{ }^{\circ} \mathrm{C}$ with a flow

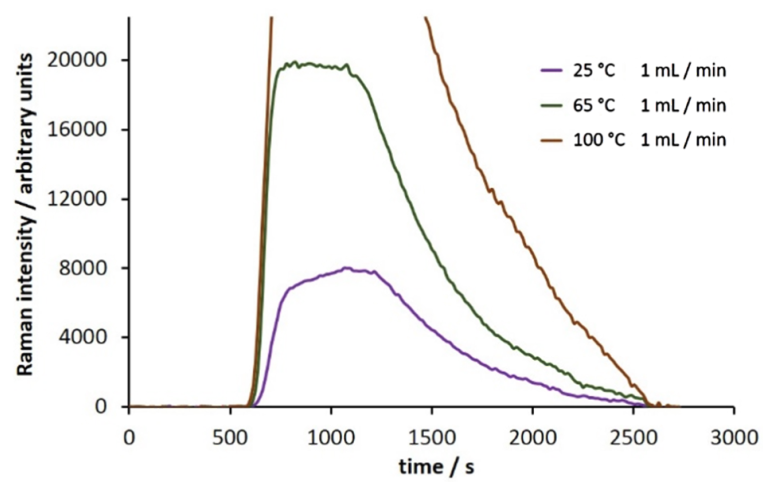

\section{Conditions}

$25{ }^{\circ} \mathrm{C}, 1 \mathrm{~mL} / \mathrm{min}$

$65^{\circ} \mathrm{C}, 1 \mathrm{~mL} / \mathrm{min}$

$100{ }^{\circ} \mathrm{C}, 1 \mathrm{~mL} / \mathrm{min}$

$65^{\circ} \mathrm{C}, 0.5 \mathrm{~mL} / \mathrm{min}$
Conversion to $3 a(\%)$

34

90 cannot monitor 
Table 3: Product conversion obtained for four aldehyde substrates in the Claisen-Schmidt reaction with acetophenone.

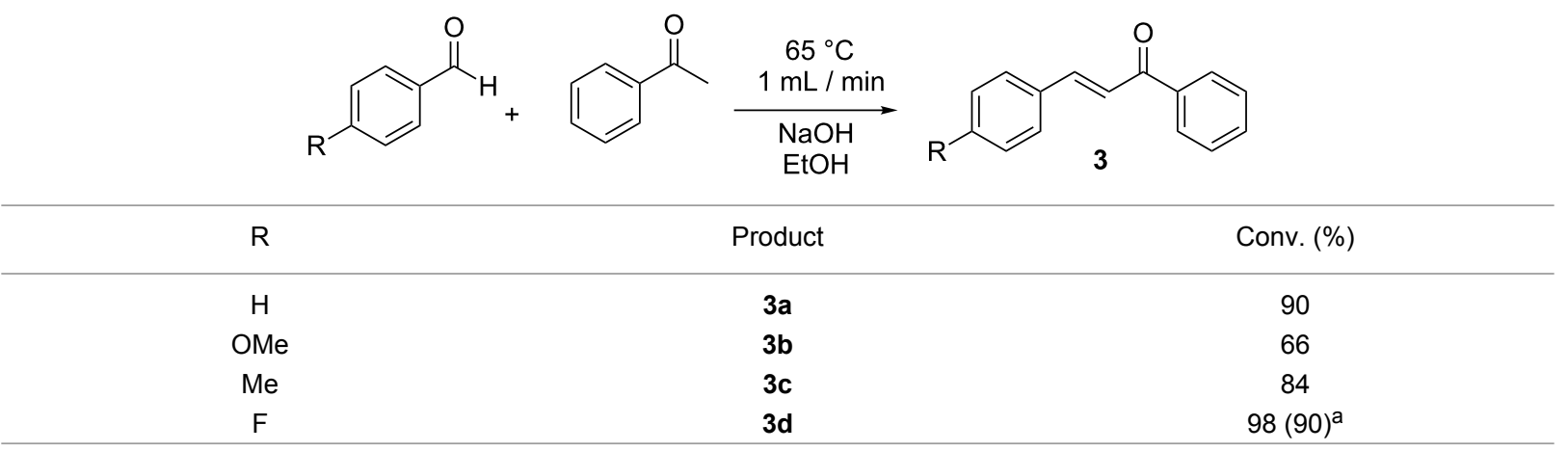

alsolated yield.

rate of $1 \mathrm{~mL} / \mathrm{min}$, this corresponding to a product conversion of $90 \%$, as determined by GC analysis. Performing the reaction under these conditions using three substituted benzaldehydes as substrates, we obtained product conversions of $66-98 \%$ depending on how electron rich or deficient the aromatic ring of the aldehyde was (Table 3).

\section{The Biginelli reaction}

As our final reaction for study, we turned to the Biginelli reaction (Scheme 4) [43-48]. This acid-catalyzed cyclocondensation of urea, $\beta$-ketoesters and aromatic aldehydes to yield dihydropyrimidines has received significant attention, these products having pharmacological activity including calcium channel modulation, mitotic kinesin Eg5 inhibition, and antiviral and antibacterial activity $[49,50]$. The Biginelli reaction has been performed in flow previously as a route to densely functionalized heterocycles using $\mathrm{HBr}$ generated in a prior step as the catalyst for the reaction [51]. Copper catalysis has also been used in flow mode for preparing PEG-immobilized dihydropyrimidines [52]. We decided to screen a set of conditions for the<smiles>O=Cc1ccccc1</smiles><smiles>CCOC(=O)CC(C)=O</smiles>

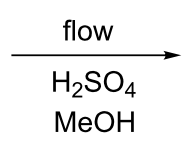<smiles>CCOC(=O)C1=C(C)NC(=O)NC1c1ccccc1</smiles>

4a<smiles>NC(N)=O</smiles>

Scheme 4: The Biginelli cyclocondensation of benzaldehyde, ethyl acetoacetate, and urea to yield 5-ethoxycarbonyl-6-methyl-4-phenyl3,4-dihydropyrimidin-2(1H)-one (4a).

reaction of benzaldehyde, ethyl acetoacetate and urea catalyzed by sulfuric acid (Figure 8 ).

The calculated Raman spectrum of the product, 4a, shows a strong signal at $1598 \mathrm{~cm}^{-1}$ which was selected for monitoring. Using a catalyst loading of $10 \mathrm{~mol} \%$ and a flow rate of $1 \mathrm{~mL} / \mathrm{min}$, we monitored the reaction over a temperature range from $25-120^{\circ} \mathrm{C}$. Seeing that the reaction did not reach completion within the $10 \mathrm{~min}$ in the heated zone, we then repeated the process at lower flow rates; first to $0.5 \mathrm{~mL} / \mathrm{min}$ and then $0.25 \mathrm{~mL} / \mathrm{min}$. Our optimal conditions as determined by Raman monitoring were heating at $120{ }^{\circ} \mathrm{C}$ with a flow rate of $0.25 \mathrm{~mL} / \mathrm{min}$, this corresponding to a product conversion of

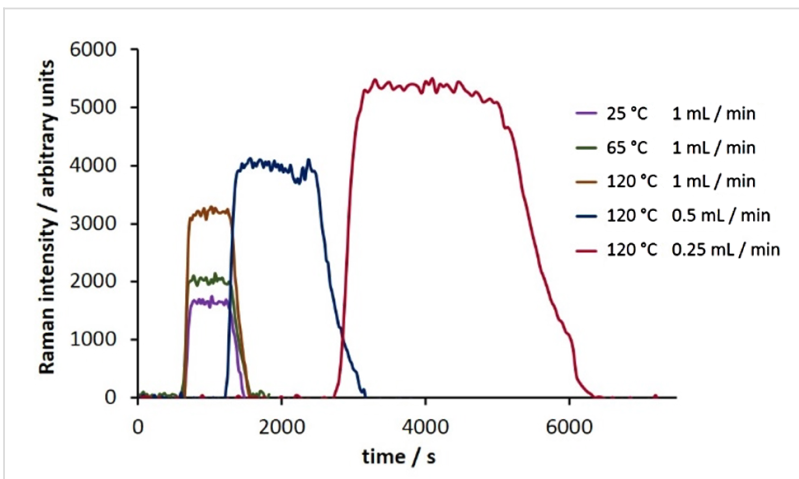

$\begin{array}{cc}\text { Conditions } & \text { Conversion to } 4 a(\%) \\ 25^{\circ} \mathrm{C}, 1 \mathrm{~mL} / \mathrm{min} & 0 \\ 65^{\circ} \mathrm{C}, 1 \mathrm{~mL} / \mathrm{min} & 5 \\ 130^{\circ} \mathrm{C}, 1 \mathrm{~mL} / \mathrm{min} & 48 \\ 130^{\circ} \mathrm{C}, 0.5 \mathrm{~mL} / \mathrm{min} & 62 \\ 30^{\circ} \mathrm{C}, 0.25 \mathrm{~mL} / \mathrm{min} & 88\end{array}$

Figure 8: Monitoring the conversion of benzaldehyde, ethyl acetoacetate, and urea to 5-ethoxycarbonyl-6-methyl-4-phenyl-3,4-dihydropyrimidin-2 $(1 H)$-one $(4 a)$ across a range of reaction conditions (scan time $=15 \mathrm{~s}$, integration $=10 \mathrm{~s}$ ). 
$89 \%$, as determined by GC analysis, and a product yield of $78 \%$ after purification. Performing the reaction using three other aldehyde substrates resulted in similar product conversions (Table 4).

Table 4: Product conversion obtained for four aldehyde substrates in the Biginelli reaction with ethyl acetoacetate and urea.

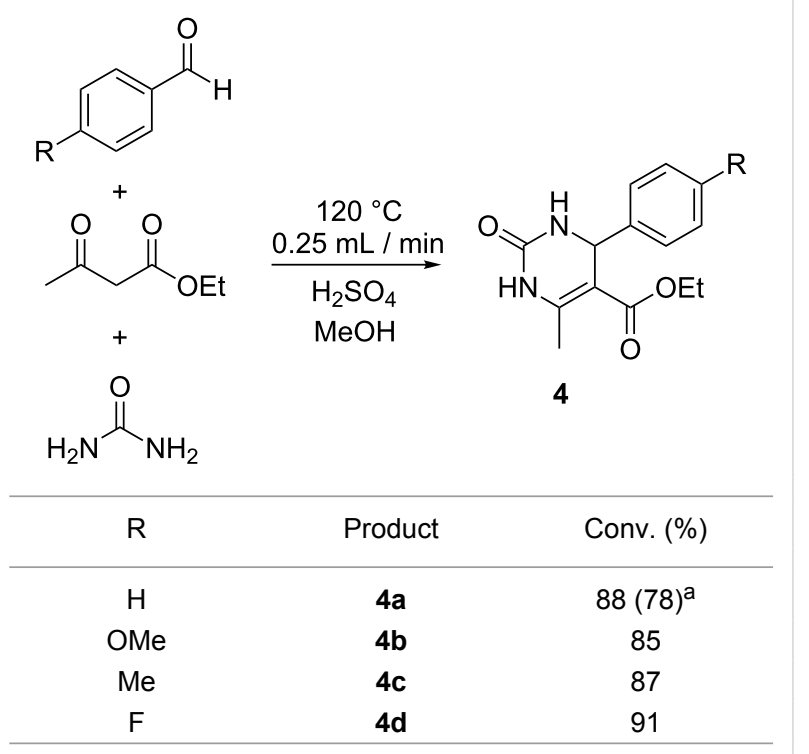

alsolated yield.

\section{Conclusion}

In conclusion, we describe here an apparatus for real-time Raman monitoring of reactions performed using continuousflow processing. We assess its capability by studying four reactions. We find that it is possible to monitor reactions and also, by means of a calibration curve, determine product conversion from Raman spectral data as corroborated by data obtained using NMR spectroscopy. Work is now underway to expand the scope of the method to other classes of useful reactions.

\section{Experimental}

\section{General experimental}

All reagents are used as received from the various vendors without purification. Sodium sulfate, $\mathrm{MeOH}, \mathrm{EtOH}, \mathrm{EtOAc}$, DMF and $\mathrm{Et}_{2} \mathrm{O}$ (ACS Grade and reagent grade), were purchased from Sigma-Aldrich and used without further purification. Deuterated NMR solvents $\left(\mathrm{CDCl}_{3}\right)$ were purchased from Cambridge Isotope Laboratories. $\mathrm{CDCl}_{3}$ stored over $4 \AA$ molecular sieves and $\mathrm{K}_{2} \mathrm{CO}_{3}$. NMR Spectra $\left({ }^{1} \mathrm{H},{ }^{13} \mathrm{C},{ }^{19} \mathrm{~F}\right)$ were performed at $298 \mathrm{~K}$ on either a Bruker DRX-400 MHz NMR, or Bruker Avance $500 \mathrm{MHz}$ NMR. ${ }^{1} \mathrm{H}$ NMR Spectra obtained in $\mathrm{CDCl}_{3}$ were referenced to residual non-deuterated chloroform (7.26 ppm) in the deuterated solvent. ${ }^{13} \mathrm{C}$ NMR Spectra obtained in $\mathrm{CDCl}_{3}$ were referenced to chloroform (77.3 ppm).
${ }^{19} \mathrm{~F}$ NMR spectra were referenced to hexafluorobenzene (-164.9 ppm) [53]. Reactions were monitored by an Agilent Technologies 7820A Gas Chromatograph attached to a 5975 Mass Spectrometer or ${ }^{1} \mathrm{H}$ NMR. Flash chromatography and silica plugs utilized Dynamic Adsorbants Inc. Flash Silica Gel (60^̊ porosity, $32-63 \mu \mathrm{m})$.

\section{Apparatus configuration}

The Raman system used was an Enwave Optronics Spectrometer, Model EZRaman-L [32]. The continuous-flow unit used was a Vapourtec E-series. A Starna 583.65.65-Q-5/Z20 flowcell (width: $6.5 \mathrm{~mm}$, height: $20 \mathrm{~mm}$, path length: $5 \mathrm{~mm}$ ) was placed inline after the back-pressure regulator using $1 \mathrm{~mm}$ i.d. PFA tubing (the void volume between the flow reactor and the flow cell was $4.79 \mathrm{~mL}$ ). The flow cell was secured in place in a custom-made box and the fiber-optic probe from the spectrometer inserted so it touched the wall of the flow cell. During a reaction, spectral data was recorded at pre-determined time intervals using the EZ Raman software provided with the instrument. The data was then exported to Excel for processing.

\section{Typical procedure for monitoring the formation of 3-acetylcoumarin (1)}

Performing the reaction: Into a $50 \mathrm{~mL}$ volumetric flask was added salicylaldehyde (6.106 g, $50 \mathrm{mmol}, 1$ equiv) and ethyl acetoacetate $(6.507 \mathrm{~g}, 50 \mathrm{mmol}, 1$ equiv). Ethyl acetate was added to bring the total volume to $50 \mathrm{~mL}(1 \mathrm{M})$ and the reagents were thoroughly mixed. An aliquot of this solution $(10 \mathrm{~mL})$ was transferred to a $20 \mathrm{~mL}$ vial equipped with a Teflon-coated stir bar. The flow reactor was readied using the equipment manufacturer's suggested start-up sequence. Ethyl acetate was pumped at $1 \mathrm{~mL} / \mathrm{min}$ to fill the reactor coil. The back-pressure regulator was adjusted to $7 \mathrm{bar}$ and the reactor coil heated to $65{ }^{\circ} \mathrm{C}$. After the heating coil, the product stream was intercepted with a stream of acetone $(1 \mathrm{~mL} / \mathrm{min})$ by means of a T-piece to ensure complete solubility of the product. The Raman probe was inserted into the box containing the flow cell and was properly focused. A background scan of the ethyl acetate/acetone solvent system was taken. This background was then automatically subtracted from all subsequent scans, thereby removing any signals from the solvent. The Raman spectrometer was set to acquire a spectrum every $15 \mathrm{~s}$ throughout the run, with $10 \mathrm{~s}$ integration time, boxcar $=3$, and average $=1$. When the flow unit was ready, piperidine $(0.099 \mathrm{~mL}$, $0.1 \mathrm{mmol}, 0.1$ equiv.) was injected all at once into the vial containing the reagents and, after mixing for $15 \mathrm{~s}$, the reaction mixture was loaded into the reactor at a flow rate of $1 \mathrm{~mL} / \mathrm{min}$. After the reaction mixture had been completely loaded into the reactor, ethyl acetate was again pumped through the coil at $1 \mathrm{~mL} / \mathrm{min}$. After the product had been fully discharged from the flow cell, the scans were halted. While the product mixture was 
passing through the flow cell, a drop of the exit stream was removed and an NMR spectrum recorded to obtain product conversion for comparison with data obtained by Raman spectroscopy. NMR conversions were determined by comparing signals from the starting salicylaldehyde $(9.84 \mathrm{ppm})$ and the coumarin product (8.45 ppm) [36].

Obtaining a relationship between signal strength and concentration: To obtain a calibration curve, spectra of 3-acetylcoumarin in 1:1 ethyl acetate/acetone were recorded at a range of concentrations by passing the solutions through the flow cell. A plot of signal strength due to the peak at $1608 \mathrm{~cm}^{-1}$ versus concentration of $\mathbf{1}$ was constructed (Figure 5). From this, units of Raman intensity could be converted to units of concentration in standard terms and hence product conversion determined.

\section{Typical procedure for monitoring the Knoevenagel reaction}

An analogous approach was used to prepare the Knoevenagel product as for the case of $\mathbf{1}$, benzaldehyde (5.306 g, $50 \mathrm{mmol}, 1$ equiv) being used in place of salicylaldehyde and there being no need for acetone interception of the product mixture. The Raman spectrometer was programmed to take continuous scans using the same parameters as in the case of $\mathbf{1}$. After the product had been fully discharged from the flow cell, the scans were halted. The resulting clear yellow solution was poured over aqueous $2 \mathrm{M} \mathrm{HCl}$ and extracted with ethyl acetate. The combined organic layers were washed with brine, dried over sodium sulfate, and the solvent was removed in vacuo by rotary evaporation affording the crude product. The crude product was loaded on a $15-\mathrm{cm}$ silica gel column (55 g silica gel) and a gradient eluting system (99:1, 95:5, 90:10; Hex:EtOAc) was used to obtain $(Z)$-ethyl 2-benzylidene-3-oxobutanoate (2a, $1.3095 \mathrm{~g}, 60 \%)$ as a clear yellow oil. ${ }^{1} \mathrm{H} \mathrm{NMR}\left(\mathrm{CDCl}_{3}, 400\right.$ $\mathrm{MHz}) \delta \mathrm{ppm} 1.26(\mathrm{t}, J=7.21 \mathrm{~Hz}, 3 \mathrm{H}), 2.41(\mathrm{~s}, 3 \mathrm{H}), 4.32(\mathrm{q}, J=$ $7.09 \mathrm{~Hz}, 2 \mathrm{H}), 7.33-7.41$ (m, 3H), 7.42-7.47 (m, 2H), 7.56 (s, $1 \mathrm{H}) ;{ }^{13} \mathrm{C} \mathrm{NMR}\left(\mathrm{CDCl}_{3}, 100 \mathrm{MHz}\right) \delta \mathrm{ppm} 14.08\left(\mathrm{CH}_{3}\right), 26.74$ $\left(\mathrm{CH}_{3}\right), 61.92\left(\mathrm{CH}_{2}\right), 129.06(\mathrm{CH}), 129.74(\mathrm{CH}), 130.93(\mathrm{CH})$, 133.17 (C), 134.88 (C), $141.48(\mathrm{CH}), 168.00$ (C), 194.87 (C) [54].

\section{Typical procedure for monitoring the Claisen-Schmidt reaction}

Into a $50 \mathrm{~mL}$ volumetric flask was added 4-fluorobenzaldehyde (1.551 g, 12.5 mmol, 1 equiv) and acetophenone (1.637 g, 12.5 mmol, 1 equiv). Ethanol was added to bring the total volume to $50 \mathrm{~mL}(0.25 \mathrm{M})$ and the reagents were thoroughly mixed. An aliquot of this solution $(10 \mathrm{~mL})$ was transferred to a $20 \mathrm{~mL}$ vial equipped with a Teflon-coated stir bar. The flow reactor was readied using the equipment manufacturer's suggested start-up sequence. Ethanol was pumped at $0.5 \mathrm{~mL} / \mathrm{min}$ to fill the reactor coil. The back-pressure regulator was adjusted to 7 bar and the reactor coil heated to $65^{\circ} \mathrm{C}$. After the heating coil, the product stream was intercepted with a stream of acetone $(0.5 \mathrm{~mL} / \mathrm{min})$ by means of a T-piece to ensure complete solubility of the product. The Raman spectrometer was configured as in the case of monitoring formation of $\mathbf{1}$. When the flow unit was ready, $2 \mathrm{M}$ $\mathrm{NaOH}(0.125 \mathrm{~mL}, 0.25 \mathrm{mmol})$ was injected all at once and after mixing for $15 \mathrm{~s}$ the reaction mixture was loaded into the reactor coil at a flow rate of $0.5 \mathrm{~mL} / \mathrm{min}$. After the reaction mixture had been completely loaded into the reactor, ethanol was again pumped through the coil at $0.5 \mathrm{~mL} / \mathrm{min}$. After the product had been fully discharged from the flow cell, the scans were halted. The yellow product solution was poured into a beaker containing ice $(100 \mathrm{~g})$ causing an immediate precipitation of the product. To ensure complete precipitation, the solution was stirred at $0{ }^{\circ} \mathrm{C}$. The solid product was collected via vacuum filtration and washed with cold ethanol. The material was dried in air to yield (E)-3-(4-fluorophenyl)-1-phenylprop-2-en-1-one, (3d, $0.5421 \mathrm{~g}, 91 \%)$ as a pale yellow solid. ${ }^{1} \mathrm{H} \mathrm{NMR}\left(\mathrm{CDCl}_{3}\right.$, $400 \mathrm{MHz}) \delta \mathrm{ppm} 7.11(\mathrm{t}, J=8.68 \mathrm{~Hz}, 2 \mathrm{H}), 7.46(\mathrm{~d}, J=15.89$ $\mathrm{Hz}, 1 \mathrm{H}), 7.49-7.55(\mathrm{~m}, 2 \mathrm{H}), 7.56-7.69(\mathrm{~m}, 3 \mathrm{H}), 7.78(\mathrm{~d}, J=$ $15.65 \mathrm{~Hz}, 1 \mathrm{H}), 8.02(\mathrm{~d}, J=7.34 \mathrm{~Hz}, 2 \mathrm{H}) ;{ }^{13} \mathrm{C} \mathrm{NMR}\left(\mathrm{CDCl}_{3}\right.$, $100 \mathrm{MHz}) \delta \mathrm{ppm} 116.42\left(\mathrm{~d}, J_{\mathrm{C}-\mathrm{C}-\mathrm{F}}=22.01 \mathrm{~Hz}, \mathrm{CH}\right), 122.09(\mathrm{~d}$, $\left.J_{\mathrm{C}-\mathrm{C}-\mathrm{C}-\mathrm{C}-\mathrm{F}}=2.20 \mathrm{~Hz}, \mathrm{C}\right), 128.76(\mathrm{~s}, 10 \mathrm{C}), 128.94(\mathrm{~s}, 9 \mathrm{C})$, $130.62\left(\mathrm{~d}, J_{\mathrm{C}-\mathrm{C}-\mathrm{C}-\mathrm{F}}=8.80 \mathrm{~Hz}, \mathrm{CH}\right), 131.45\left(\mathrm{~d}, J_{\mathrm{C}-\mathrm{C}-\mathrm{C}-\mathrm{C}-\mathrm{C}-\mathrm{F}}=\right.$ $3.67 \mathrm{~Hz}, \mathrm{CH}), 133.12(\mathrm{C}), 138.43(\mathrm{C}), 143.78(\mathrm{CH}), 164.35$ (d, $\left.J_{\mathrm{C}-\mathrm{F}}=250.89 \mathrm{~Hz}, \mathrm{C}\right), 190.59(\mathrm{C}) ;{ }^{19} \mathrm{~F} \mathrm{NMR}\left(\mathrm{CDCl}_{3}, 377 \mathrm{MHz}\right)$ $\delta \mathrm{ppm}-113.59,-111.32(\mathrm{~m})[55,56]$.

\section{Typical procedure for monitoring the Biginelli reac- tion}

In a $50 \mathrm{~mL}$ volumetric flask was dissolved urea $(3.003 \mathrm{~g}, 50$ mmol, 1 equiv. $)$ in methanol $(\sim 30 \mathrm{~mL})$. Into the flask was then added benzaldehyde (1.306 g, $50 \mathrm{mmol}, 1$ equiv) and ethyl acetoacetate $(6.507 \mathrm{~g}, 50 \mathrm{mmol}, 1$ equiv). Methanol was added to bring the total volume to $50(1 \mathrm{M})$ and the reagents were thoroughly mixed. An aliquot of this solution $(10 \mathrm{~mL})$ was transferred to a $20 \mathrm{~mL}$ vial equipped with a Teflon-coated stir bar. The flow reactor was readied using the equipment manufacturer's suggested start-up sequence. Methanol was pumped at $0.25 \mathrm{~mL} / \mathrm{min}$ to fill the reactor coil. The back-pressure regulator was adjusted to $7 \mathrm{bar}$ and the reactor coil heated to $120^{\circ} \mathrm{C}$. After the heating coil, the product stream was intercepted with a stream of $N, N$-dimethylformamide $(0.25 \mathrm{~mL} / \mathrm{min})$ by means of a T-piece to ensure complete solubility of the product. The Raman spectrometer was set to acquire a spectrum every $25 \mathrm{~s}$, with $20 \mathrm{~s}$ integration time, boxcar $=3$, and average $=1$. When the flow unit was ready, $6 \mathrm{M} \mathrm{H}_{2} \mathrm{SO}_{4}(0.2 \mathrm{~mL}, 0.1$ equiv) was injected all at once and after mixing for $15 \mathrm{~s}$ the reaction mixture was loaded into the reactor coil at a flow rate of 
$0.25 \mathrm{~mL} / \mathrm{min}$. After the reaction mixture had been completely loaded into the reactor, methanol was again pumped through the coil at $0.25 \mathrm{~mL} / \mathrm{min}$. After the product had been fully discharged from the flow cell, the scans were halted. The reaction mixture was transferred to a separatory funnel, diluted with diethyl ether and quenched with satd. sodium bicarbonate $(100 \mathrm{~mL})$ and deionized water $(100 \mathrm{~mL})$. The layers were separated and the aqueous layer was extracted with diethyl ether (3 $\times 100 \mathrm{~mL}$ ). The combined organic layers were washed with brine $(2 \times 100 \mathrm{~mL})$ and dried over sodium sulfate. The solvent was removed in vacuo by rotary evaporation affording the crude product. The resulting solid was transferred to a filter funnel and was washed with cold methanol. The solid was isolated and air dried to afford 5-ethoxycarbonyl-6-methyl-4-phenyl-3,4-dihydropyrimidin-2(1H)-one, $(\mathbf{4 a}, 2.030 \mathrm{~g}, 78 \%)$ as a fluffy white solid. ${ }^{1} \mathrm{H}$ NMR (DMSO- $\left.d_{6}, 500 \mathrm{MHz}\right) \delta$ ppm 1.18 (s., 3H), 2.34 (s., 3H), 3.67-4.60 (m, 2H), 5.24 (s., 1H), 7.34 (s., 5H), 7.80 (s., $1 \mathrm{H}), 7.74(\mathrm{~s}, 1 \mathrm{H}), 9.26(\mathrm{~s}, 1 \mathrm{H}) ;{ }^{13} \mathrm{C}$ NMR (DMSO- $d_{6}, 125$ $\mathrm{MHz}) \delta \mathrm{ppm} 14.5\left(\mathrm{CH}_{3}\right), 18.2\left(\mathrm{CH}_{3}\right), 54.4(\mathrm{CH}), 59.6\left(\mathrm{CH}_{2}\right)$, $99.7(\mathrm{C}), 126.7(\mathrm{CH}), 127.7(\mathrm{CH}), 128.8(\mathrm{CH}), 145.3(\mathrm{C}), 148.8$ (C), $152.6(\mathrm{C}), 165.8(\mathrm{C})$ [57].

\section{Supporting Information}

\section{Supporting Information File 1}

NMR spectra of the isolated products $(\mathbf{1}, \mathbf{2 a}, \mathbf{3 d}, \mathbf{4 a})$,

further experimental information, and pictures of the

Raman interface and Cartesian coordinates of the stationary points.

[http://www.beilstein-journals.org/bjoc/content/ supplementary/1860-5397-9-215-S1.pdf]

\section{Acknowledgements}

Funding from the National Science Foundation (CAREER award CHE-0847262) is acknowledged. Vapourtec Ltd and Enwave Optronics are thanked for equipment support. Daniel Daleb of the University of Connecticut is thanked for his support in the construction of the flow cell apparatus.

\section{References}

1. Wiles, C.; Watts, P. Micro Reaction Technology in Organic Synthesis; CRC Press: Boca Raton, FL, USA, 2011.

2. Luis, S. V.; Garcia-Verdugo, E., Eds. Chemical Reactions and Processes under Flow Conditions; Royal Society of Chemistry: Cambridge, U.K, 2010.

3. Wiles, C.; Watts, P. Chem. Commun. 2011, 47, 6512-6535. doi:10.1039/c1cc00089f

4. Wegner, J.; Ceylan, S.; Kirschning, A. Chem. Commun. 2011, 47, 4583-4592. doi:10.1039/c0cc05060a

5. Razzaq, T.; Kappe, C. O. Chem.-Asian J. 2010, 5, 1274-1289. doi:10.1002/asia.201000010
6. Mark, D.; Haeberle, S.; Roth, G.; von Stetten, F.; Zengerle, R. Chem. Soc. Rev. 2010, 39, 1153-1182. doi:10.1039/b820557b

7. van den Broek, S. A. M. W.; Leliveld, J. R.; Delville, M. M. E.; Nieuwland, P. J.; Koch, K.; Rutjes, F. L. J. T. Org. Process Res. Dev. 2012, 16, 934-938. doi:10.1021/op2003437

8. Baxendale, I. R. J. Chem. Technol. Biotechnol. 2013, 88, 519-552. doi:10.1002/jctb.4012

9. Malet-Sanz, L.; Susanne, F. J. Med. Chem. 2012, 55, 4062-4098. doi:10.1021/jm2006029

10. McMullen, J. P.; Jensen, K. F. Annu. Rev. Anal. Chem. 2010, 3, 19-42. doi:10.1146/annurev.anchem.111808.073718

11. Moore, J. S.; Jensen, K. F. Org. Process Res. Dev. 2012, 16 , 1409-1415. doi:10.1021/op300099x

12. Prim, D.; Crelier, S.; Segura, J.-M. Chimia 2011, 65, 815-816. doi:10.2533/chimia.2011.815

13. Greener, J.; Abbasi, B.; Kumacheva, E. Lab Chip 2010, 10 , 1561-1566. doi:10.1039/c001889a

14. Steinfeldt, N.; Bentrup, U.; Jähnisch, K. Ind. Eng. Chem. Res. 2010, 49, 72-80. doi:10.1021/ie900726s

15. Floyd, T. M.; Schmidt, M. A.; Jensen, K. F. Ind. Eng. Chem. Res. 2005, 44, 2351-2358. doi:10.1021/ie049348j

16. Ferstl, W.; Klahn, T.; Schweikert, W.; Billeb, G.; Schwarzer, M.; Loebbecke, S. Chem. Eng. Technol. 2007, 30, 370-378. doi:10.1002/ceat.200600404

17. Benito-Lopez, F.; Verboom, W.; Kakuta, M.; Gardeniers, J. G. E.; Egberink, R. J. M.; Oosterbroek, E. R.; van den Berg, A.; Reinhoudt, D. N. Chem. Commun. 2005, 2857-2859. doi:10.1039/b500429b

18. Lu, H.; Schmidt, M. A.; Jensen, K. F. Lab Chip 2001, 1, 22-28. doi:10.1039/b104037p

19. Gökay, O.; Albert, K. Anal. Bioanal. Chem. 2012, 402, 647-669. doi:10.1007/s00216-011-5419-z

20. Jones, C. J.; Larive, C. K. Anal. Bioanal. Chem. 2012, 402, 61-68. doi:10.1007/s00216-011-5330-7

21. Mozharov, S.; Nordon, A.; Littlejohn, D.; Wiles, C.; Watts, P.; Dallin, P.; Girkin, J. M. J. Am. Chem. Soc. 2011, 133, 3601-3608. doi:10.1021/ja1102234

22. Rinke, G.; Ewinger, A.; Kerschbaum, S.; Rinke, M. Microfluid. Nanofluid. 2011, 10, 145-153. doi:10.1007/s10404-010-0654-8

23. Leung, S. A.; Winkle, R. F.; Wootton, R. C. R.; deMello, A. J. Analyst 2005, 130, 46-51. doi:10.1039/b412069h

24. Lee, M.; Lee, J.-P.; Rhee, H.; Choo, J.; Chai, Y. G.; Lee, E. K. J. Raman Spectrosc. 2003, 34, 737-742. doi:10.1002/jrs.1038

25. Fletcher, P. D. I.; Haswell, S. J.; Zhang, X. Electrophoresis 2003, 24 , 3239-3245. doi:10.1002/elps.200305532

26. Browne, D. L.; Wright, S.; Deadman, B. J.; Dunnage, S.; Baxendale, I. R.; Turner, R. M.; Ley, S. V. Rapid Comm. Mass. Spectrosc. 2012, 26, 1999-2010. doi:10.1002/rcm.6312

27. Koster, S.; Verpoorte, E. Lab Chip 2007, 7, 1394-1412. doi:10.1039/b709706a

28. Carter, C. F.; Lange, H.; Ley, S. V.; Baxendale, I. R.; Wittkamp, B.; Goode, J. G.; Gaunt, N. L. Org. Process Res. Dev. 2010, 14, 393-404. doi:10.1021/op900305v

29. Brodmann, T.; Koos, P.; Metzger, A.; Knochel, P.; Ley, S. V. Org. Process Res. Dev. 2012, 16, 1102-1113. doi:10.1021/op200275d 30. Rueping, M.; Bootwicha, T.; Sugiono, E. Beilstein J. Org. Chem. 2012, 8, 300-307. doi:10.3762/bjoc.8.32 
31. Leadbeater, N. E.; Schmink, J. R.; Hamlin, T. A. In Microwaves in Organic Synthesis, 3rd ed.; de la Hoz, A.; Loupy, A., Eds.; Wiley-VCH: Weinheim, Germany, 2012.

32. Leadbeater, N. E.; Schmink, J. R. Nat. Protoc. 2008, 3, 1-7. doi:10.1038/nprot.2007.453

33. Leadbeater, N. E.; Smith, R. J.; Barnard, T. M. Org. Biomol. Chem. 2007, 5, 822-825. doi:10.1039/b615597a

34. Leadbeater, N. E.; Smith, R. J. Org. Lett. 2006, 8, 4589-4591. doi:10.1021/ol061803f

35. Leadbeater, N. E.; Smith, R. J. Org. Biomol. Chem. 2007, 5, 2770-2774. doi:10.1039/b707692d

36. Schmink, J. R.; Holcomb, J. L.; Leadbeater, N. E. Chem.-Eur. J. 2008, 14, 9943-9950. doi:10.1002/chem.200801158

37. Schmink, J. R.; Holcomb, J. L.; Leadbeater, N. E. Org. Lett. 2009, 11, 365-368. doi:10.1021/ol802594s

38. Chaplain, G.; Haswell, S. J.; Fletcher, P. D. I.; Kelly, S. M.; Mansfield, A. Aust. J. Chem. 2013, 66, 208-212. doi:10.1071/CH12379

39. Kelly, C. B.; Lee, C.; Leadbeater, N. E. Tetrahedron Lett. 2011, 52, 263-265. doi:10.1016/j.tetlet.2010.11.027

40. Gaussian 09, Revision A.02; Gaussian, Inc.: Wallingford CT, , 2009.

41. Batovska, D. I.; Todorova, I. T. Curr. Clin. Pharmacol. 2010, 5, 1-29. doi:10.2174/157488410790410579

42. Bowman, M. D.; Jacobson, M. M.; Blackwell, H. E. Org. Lett. 2006, 8 , 1645-1648. doi:10.1021/ol0602708

43. Singh, K.; Singh, K. Adv. Heterocycl. Chem. 2012, 105, 223-308. doi:10.1016/B978-0-12-396530-1.00003-6

44. Panda, S. S.; Khanna, P.; Khanna, L. Curr. Org. Chem. 2012, 16, 507-520. doi:10.2174/138527212799499859

45. Kappe, C. O. QSAR Comb. Sci. 2003, 22, 630-645. doi:10.1002/qsar.200320001

46. Mukhopadhyay, C.; Datta, A.; Banik, B. K. J. Heterocycl. Chem. 2011, 44, 979-981. doi:10.1002/jhet.5570440439

47. Fang, Z.; Lam, Y. Tetrahedron 2011, 67, 1294-1297. doi:10.1016/j.tet.2010.11.075

48. Dallinger, D.; Kappe, C. O. Nat. Protoc. 2007, 2, 317-321. doi:10.1038/nprot.2006.436

49. Singh, K.; Arora, D.; Singh, K.; Singh, S. Mini-Rev. Med. Chem. 2009, 9, 95-106. doi:10.2174/138955709787001686

50. Kappe, C. O. Eur. J. Med. Chem. 2000, 35, 1043-1052. doi:10.1016/S0223-5234(00)01189-2

51. Pagano, N.; Herath, A.; Cosford, N. D. P. J. Flow Chem. 2011, 1, 28-31. doi:10.1556/jfchem.2011.00001

52. Prosa, N.; Turgis, R.; Piccardi, R.; Scherrmann, M.-C. Eur. J. Org. Chem. 2012, 2188-2200. doi:10.1002/ejoc.201101726

53. Ravikumar, I.; Saha, S.; Ghosh, P. Chem. Commun. 2011, 47, 4721-4723. doi:10.1039/c0cc03469j

54. Li, Z.-N.; Chen, X.-L.; Fu, Y.-J.; Wang, W.; Luo, M. Res. Chem. Intermed. 2012, 38, 25-35. doi:10.1007/s11164-011-0322-y

55. Stroba, A.; Schaeffer, F.; Hindie, V.; Lopez-Garcia, L.; Adrian, I.; Froehner, W.; Hartmann, R. W.; Biondi, R. M.; Engel, M. J. Med. Chem. 2009, 52, 4683-4693. doi:10.1021/jm9001499

56. Wijnberg, H.; Vries, T. R.; Pouwer, K.; Nieuwenhuijzen, J. 3-Oxopropane-1-sulphonic acids and sulphonates. U.S. Patent 6,639,103, Oct 28, 2003.

57. Xu, D.-Z.; Li, H.; Wang, Y. Tetrahedron 2012, 68, 7867-7872. doi:10.1016/j.tet.2012.07.027

\section{License and Terms}

This is an Open Access article under the terms of the Creative Commons Attribution License

(http://creativecommons.org/licenses/by/2.0), which permits unrestricted use, distribution, and reproduction in any medium, provided the original work is properly cited.

The license is subject to the Beilstein Journal of Organic Chemistry terms and conditions:

(http://www.beilstein-journals.org/bjoc)

The definitive version of this article is the electronic one which can be found at:

doi:10.3762/bjoc.9.215 